\title{
GENETIC COMPARISON OF WHITEFRINGED WEEVIL SPECIES AND POPULATIONS BY RAPD-PCR
}

\author{
S. HARDWICK ${ }^{1}$, K.F. ARMSTRONG ${ }^{2}$, S.D. WRATTEN ${ }^{2}$ \\ and R.A. PRESTIDGE ${ }^{1}$
}

\author{
${ }^{1}$ AgResearch, Ruakura Research Centre, Private Bag 3123 Hamilton \\ ${ }^{2}$ Department of Entomology and Animal Ecology, PO Box 84 Lincoln University
}

\begin{abstract}
A RAPD-PCR technique was used to compare genetic material from three species (Naupactus leucoloma, N. peregrinus, and N.tucumanensis) of whitefringed weevil.N. peregrinus, $N$. tucumanensis and $N$. leucolomawere consistently distinguished from each other by the presence or absence of RAPD bands. The banding profiles obtained suggested that $N$. peregrinus is genetically more closely related to $N$. leucolomathan N. tucumanensis. The technique distinguished between three "clones" in twoN. leucoloma populations sampled from Australia and New Zealand. No differences were detected between individuals within $N$. tucumanensis or $N$. peregrinus populations. The potential for RAPD-PCR technique to provide useful genetic data at the population level is discussed.
\end{abstract}

Keywords: Naupactus leucoloma, Naupactus peregrinus, Naupactus tucumanensis, RAPD-PCR analysis

\section{INTRODUCTION}

Whitefringed weevil,Naupactus leucoloma(Boheman)(Coleoptera: Curculionidae), has rapidly become established in lowland pastures of both the North and South Islands of New Zealand since first being found in 1945 (Todd 1968). Whitefringed weevil is thought to have been introduced into New Zealand from North America. In New Zealand, the weevil is parthenogenetic with no known incidence of males (East 1980) and has a generation time of 12-18 months in the northern North Island (Hardwick and Prestidge 1994) and up to 24 months in less favorable conditions (May 1975). With the banning of the residual soil insecticides DDT and dieldrin, control of the damaging root feeding whitefringed weevil larvae in pasture has become more difficult.

Elucidation of genetic variability in introduced pest populations is an important aspect of pest studies. For whitefringed weevil this may be important in the development of alternative control measures, for example by providing information on the geographical origin of the colonising populations of weevil and of candidate parasitoids for biological control, and also the behavioral and ecological interactions between them (Armstrong and Wratten 1996). Within the native habitat, the extent of genetic variation between geographic populations depends on factors such as gene flow between populations and time since separation (Hartl 1980). In introduced populations, the genetic make up of pest populations also depends on several factors including the genetic makeup of the founder population, the number of introductions that have occurred over time, and the amount of selection pressure exerted by the new environment (Baker and Stebbins 1965; Williamset al. 1994). In order to determine the origin of pest populations, it is necessary to demonstrate the genetic similarities between introduced or colonised populations and the potential source populations (Williams et al. 1994). In species such as whitefringed weevil for which there is no published gene sequence data, one method of describing populations at the molecular level is through the polymerase chain reaction (PCR) based random amplification of polymorphic DNA (RAPD) (Williamsetal. 1990). This method has also been successfully used to identify genetic variation in populations of other 
parthenogenetically reproducing species (e.g. Black et al. 1992; de Barro et al. 1995; Nicol et al. 1997).

This paper reports a study assessing the ability of the RAPD-PCR technique to differentiate between species of whitefringed weevil and populations of $N$. leucoloma from Victoria, Australia and Hamilton, New Zealand.

\section{Sample collection}

\section{MATERIALS AND METHODS}

In March 1994 adultN. leucoloma were collected from a single paddock at Ruakura Research Centre, Hamilton, New Zealand $(n=100)$ and from a single paddock in Bannockburn, Victoria Australia $(n=40)$. All samples were stored frozen at $-80^{\circ} \mathrm{C}$. Larvae $(\mathrm{n}=50)$ of $N$. peregrinus from a North American population (laboratory colony maintained at Auburn University Alabama), and adult $N$. tucumanensis $(\mathrm{n}=5)$ from a South American (Villa de las Rosa, Cordoba, Argentina) population were also obtained; both larvae and adults were stored in $95 \%$ ethanol at $4^{\circ} \mathrm{C}$.

\section{DNA isolation}

Individual weevils were cut into several pieces using a sterilized scalpel blade and the tissue digested with $500 \mathrm{ml}$ of isolation buffer $(8.5 \mathrm{mM}$ Tris $\mathrm{pH} 8 ; 50 \mathrm{mM}$ ETDA pH 8; $0.5 \%$ SDS and $0.5 \mathrm{mg} \mathrm{ml}^{-1}$ Proteinase $\mathrm{K}$ ) at $50^{\circ} \mathrm{C}$ for three hours with occasional inversion. DNA was extracted using the high-salt and ethanol precipitation method outlined in Miller et al. (1988) and then re-dissolved in $200 \mathrm{ml}$ of TE ( $10 \mathrm{mM}$ Tris pH $8.0 ; 0.1 \mathrm{mM}$ Tris). The quality and quantity of DNA was determined by the absorbance at $260 \mathrm{~nm}$ and $280 \mathrm{~nm}$ (Kirby 1990) and comparison with 1 DNA resolved by agarose gel electrophoresis. Using this method the DNA of $100 \mathrm{~N}$. leucoloma from Ruakura, New Zealand, 40 N. leucoloma from Bannockburn, Australia, 50 N. peregrinus from Auburn, North America, and 5 N. tucumanensis from Villa de las Rosa, Cordoba, Argentina was extracted.

\section{Primers}

Random sequence 10-mer primers were obtained from Operon Technologies (Alameda California). Thirty primers were initially screened using DNA extracted from two whitefringed weevil individuals from the Ruakura population. Primers that generated too many bands (>10 per sample) or weak indistinct banding patterns were discarded. Ten suitable primers were further tested using ten individuals from the Ruakura population. Three of these primers (OPA-01 (5'-CAGGCCCTTC-3'), OPK-01 (5'CATTCGAGCC-3') and OPK-16 (5'-AGCCAAGCGAA-3')) were selected for the full population analysis as they generated between 5-10 distinct bands and showed polymorphisms between individuals.

\section{PCR protocols and electrophoresis}

RAPD reactions were carried out based on the methods developed by Williamset al. (1990) and Welsh and McClelland (1990). Reaction volumes of $25 \mu 1$ contained $1.0 \mathrm{mM}$ dNTPs, 1x Taq polymerase buffer (Boehringer Mannheim), $0.5 \mathrm{mM} \mathrm{MgCl}, 0.4$ units Taq polymerase, $2.5 \mathrm{ng}$ template DNA and $0.2 \mathrm{mM}$ primer. A negative control (without template DNA) was included in each set of reactions amplified. All reactions were carried out on a Perkin-Elmer Cetus 2400 thermal cycler and employed the hot start technique (D'Aquila et al. 1991). The cycling regime consisted of an initial denaturing step of 95 ${ }^{\circ} \mathrm{C}$ for 5 minutes followed by the addition of the Taq polymerase $(2 \mu \mathrm{l}$ of a diluted stock) at $72{ }^{\circ} \mathrm{C}$ and then 40 cycles of $15 \mathrm{~s} 93^{\circ} \mathrm{C}, 15 \mathrm{~s} 37^{\circ} \mathrm{C}$ and $20 \mathrm{~s} 71^{\circ} \mathrm{C}$. A final extension step of 5 minutes at $72^{\circ} \mathrm{C}$ was followed by a $10^{\circ} \mathrm{C}$ soak until the samples were recovered from the thermal cycler and stored at $4{ }^{\circ} \mathrm{C}$.

Aliquots $(5 \mu \mathrm{l})$ of the amplification products were then electrophoresed at $4.5 \mathrm{~V} \mathrm{~cm}^{-}$ ${ }^{1}$ constant voltage for 1.5 hours through a $1.2 \%$ Seakem LE Agarose in TBE (44 mM Tris; $53 \mathrm{mM}$ boric acid; $1 \mathrm{mM}$ EDTA) buffer containing $0.08 \mu \mathrm{g} / \mathrm{ml}$ ethidium bromide. The PCR products were visualized over UV light. Each sample was replicated by amplifying under the same PCR conditions in different tubes on the same or on different days.

\section{Scoring of bands}

Each individual was scored for the presence (1) or absence (0) of all bands identified. 
Homologous bands were considered as those migrating the same distance relative to a molecular weight marker (BRL 100bp, Gibco-BRL) although this could have included comigration of different loci (Black 1993). Homology between gels was verified by running an aliquot of representative individuals from each gel that contained the band of interest side by side on a subsequent gel. Similarity matrices were calculated from the data on the presence or absence of bands for each sample population. A binomial comparison using Genstat (Genstat 1987) was then made between all bands. Genetic distance or similarity was determined by using three methods to provide a cross check on interpretation (Jaquard similarity genetic distance (Gower 1985), band sharing (Hedrick 1985) and Nei and Lei band sharing (Nei and Lei 1979)). Dendograms were constructed from the similarity matrices by hierarchical cluster analysis using the Nei and Lie statistics. All samples collected were included in the analysis.

\section{RESULTS}

Reproducibility of the method was confirmed as the same banding profiles were obtained for the sample replicates. Across all individuals tested, the three primers produced 70 scorable bands in total. For $N$. leucolomaeach primer produced three distinctly different banding patterns. Individuals always separated into the same group, irrespective of the primer used. Two patterns were observed in the Ruakura population, subsequently referred to as "clones" A and B, which made up 57\% and $43 \%$ of the population respectively, and a third from Victoria, "Clone" C. A schematic example of the banding patterns produced when DNA was amplified with primer OPA-01 is shown (Fig. 1). Similarity matrices constructed from this data revealed that $N$. leucoloma clones A and B at Ruakura are more similar to each other (sharing $75 \%$ of their bands), relative to the Australian "clone" C (sharing 55\% of its bands) (Fig. 2). The two other Naupactus species are even more

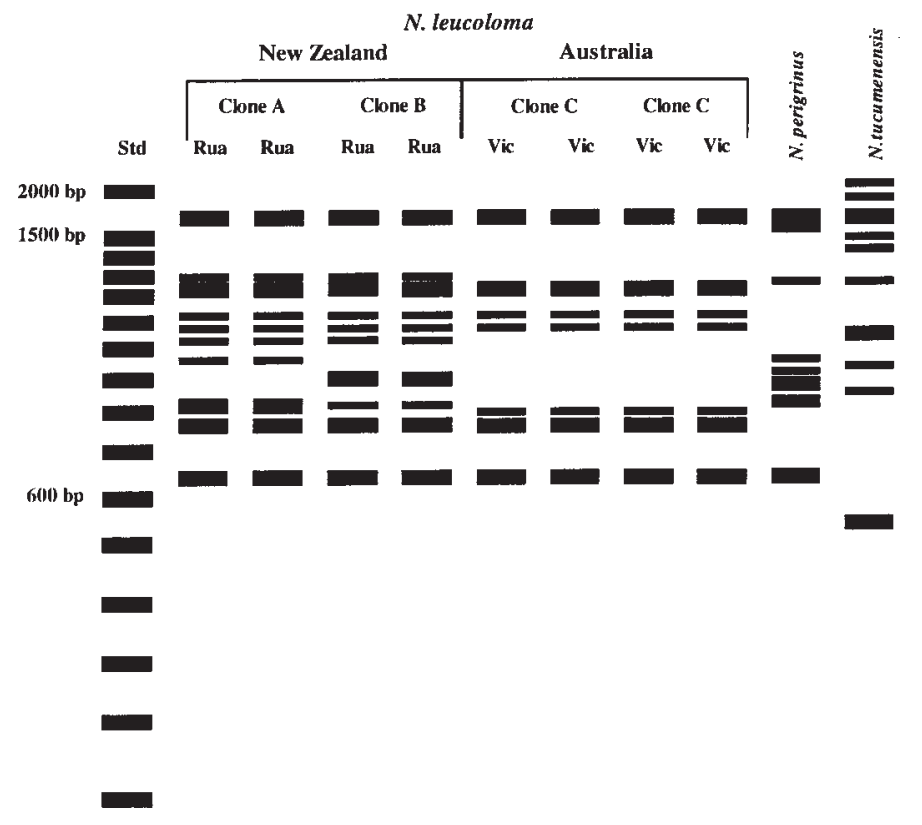

FIGURE 1: Schematic representation of an electrophoresis gel of the PCR products produced using primer OPA-01 (thinner bands indicate faint bands). 
different.N. peregrinus shared approximately $50 \%$ of its bands withN. leucolomafrom the Ruakura population, while N. tucumanensis shared around $40 \%$ of its bands with $N$. leucolomafrom Ruakura (Fig. 2). No genetic variation was found withinN. peregrinus and $N$. tucumanensis populations, though the number sampled of the latter was very low. All primers produced 1 or 2 bands which were shared by $N$. leucoloma and $N$. peregrinus but not by N. tucumanensis, for example, bands at $640 \mathrm{bp}$ (Fig. 1). However there were bands common to all three species, for example at 1700 bp using primer OPA-01 (Fig. 1).

\section{DISCUSSION}

RAPD analysis of the three species of whitefringed weevil appeared to confirm the species distinctions determined on morphological criteria as outlined in Lanteri and

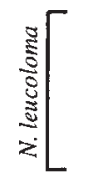

$$
\begin{array}{r}
\text { Ruakura Clone A } \\
\text { Ruakura Clone B } \\
\text { Victoria Clone C } \\
\text { N. peregrinus } \\
\text { N. tucumanensis }
\end{array}
$$
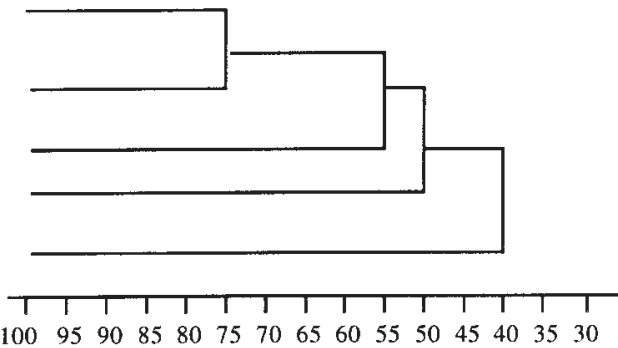

Relative genetic distance

\section{FIGURE 2: Dendogram showing the relationship based on RAPD analysis between species and populations of $N$. leucoloma (Australia, New Zealand), $N$. peregrinus (USA) and $N$. tucumanensis (Argentina) (Results of 70 scorable bands using three selected primers).}

Marvaldi (1995). In addition, analysis also showed that $N$. leucolomaand N. peregrinus appeared to be more closely related to each other than to $N$. tucumanensis.

As well as discriminating at the species level, the technique could also detect population level variation. For N. leucoloma the level of variation found within and between populations is of the same order as that found using the same technique with parthenogenetic populations of other insect species (Blacket al. 1992; Nicolet al. 1997) and lower than that of sexually reproducing populations (Black et al. 1992). Limited variation in populations of $N$. leucoloma and $N$. peregrinus may be expected as these species are reported to reproduce exclusively by parthenogenesis outside of South America (Lanteri and Normark 1995). In the absence of a sexual phase, and therefore meiotic recombination, genetic variation will be limited to rare events of beneficial mutations, chromosomal rearrangements and mitotic recombination (Hughes 1989). This lack of variation in the absence of a sexual phase would be compounded as $N$. leucoloma has a long generation time and would therefore have produced a small number of generations since its introduction into New Zealand 50-60 years ago.

In this relatively limited study two "clones" were detected in a single New Zealand paddock. This could be due to contamination of weevil DNA, natural genetic variation or multiple introductions. Contamination of the samples with non-target DNA such as soil organisms, plant material or internal parasites could have occurred at the time of collection. Contamination of samples can be a problem in field collected samples as they are often collected in primitive conditions (Ellsworthet al. 1993). However contamination of DNA samples and PCR reaction mix is unlikely as results were reproducible and had clean negative controls.

There are no records of any parasites or diseases occurring in field populations of $N$. leucoloma in New Zealand. HoweverN. leucolomalarvae in Australian populations are attacked by the parasitic nematode Heterorhabditis spp. (Sexton and Williams 1981) 
which causes infected larvae to turn brick-red in colour. All whitefringed weevil collected for this study were visually inspected for disease or parasitism when collected and again when being processed for DNA extraction and none appeared to be diseased or parasitised. Studies of aphids have shown that changes in banding profiles obtained using RAPD-PCR on parasitised aphids did not occur until it was visually obvious they were parasitised (Black et al. 1992). Therefore it seems unlikely that parasitism or disease is the cause of the variation in banding patterns within the Ruakura paddock.

Natural variation due to beneficial mutations, chromosomal rearrangements and mitotic recombination large enough to cause the observed differences in RAPD-PCR profiles within the Ruakura population may have occurred. Multiple introduction of $N$. leucoloma may also be the cause of this variation in banding profiles within the Ruakura population. Due to the small number of N. leucolomapopulations examined in this study these two possibilities cannot be discounted as there is no knowledge of the amount of genetic variation that occurs in other native or introduced populations. Therefore another study which includes a number of geographically distant introduced and native populations of $N$. leucoloma is needed to determine the genetic diversity of other populations.

This initial genetic characterisation of $N$. peregrinus, N. tucumanensis and $N$. leucoloma populations has illustrated that the RAPD-PCR technique can be used to distinguish between individuals at both the species and population level. If banding patterns similar to those of New Zealand populations can be found in other introduced or native populations around the world, a place of origin could be inferred. This in turn could provide useful information toward the rational introduction of biological control agents.

\section{ACKNOWLEDGEMENTS}

We thank Charlotte Cameron and Christine Lahmann, Lincoln University for technical assistance and Neil Cox, AgResearch Ruakura for assisting with the statistical analysis, Dr John Matthiessen, CSIRO, for the collection and transport of the Australian samples of N. leucoloma, Dr Geoff Zhender, Auburn University, Alabama, for the collection and transport of $N$. peregrinus and Dr B. Normark, Cornell University, for the collection and transport of $N$. tucumanensis samples.

\section{REFERENCES}

Armstrong, K.F. and Wratten, S.D., 1996. The use of DNA analysis and the polymerase chain reaction in the study of introduced pests in New Zealand. Pp 231-263In: The Ecology of Agricultural Pests, W.O.C., Symondson and J.E. Liddell(Eds), Chapman and Hall, Melbourne.

Baker, H.G. and Stebbins, G.L., 1965. The Genetics of Colonising Species. New York Academic Press, New York.

Black, W.C., 1993. PCR with arbitrary primers: approach with care. Insect Mol. Bio. 2: 1-6

Black, W.C., Du Teau, N.M., Puterka, G.J., Nechols, J.R. and Pettorini, J.M., 1992. Use of the random amplified polymorphic DNA polymerase chain reaction (RAPDPCR) to detect DNA polymorphisms in aphids (Homoptera: Aphididae).Bull. Ento. Res. 82: 151-159.

D’Aquila, R.T., Bechtel, L.J., Vidler, J.A., Eron, J.J., Gorezyca, P. and Kaplan, J.C., 1991. Maximising sensitivity and specificity of PCR by preamplification heating. Nucleic Acids Res. 19: 3749.

De Barro, P.J., Sherratt T.N., Brookes C.P., David, O. and MacLean, N., 1995. Spatial and temporal genetic variation in British field populations of the grain aphid, Sitobion avena (F.) (Hemiptera. Aphididae) studied using RAPD-PCR.Proc. Roy. Soc. Lon. Series B 262: 321-327.

East, R., 1980. Sampling whitefringed weevil (Graphognathus leucoloma) populations. N.Z. J. Agri. Res. 23: 581-587.

Ellsworth, D.L., Rittenhouse, K.D. and Honeycutt, R.L., 1993. Artificial variation in randomly amplified polymorphic DNA banding patterns. Biotechniques 14: 214217. 
Genstat 5 Committee, 1987. Genstat 5 reference manual. Oxford University Press, Oxford.

Gower, J.C., 1985. Measures of similarity, dissimilarity, and distance. Pp. 397-405In: Encyclopaedia of Statistical Sciences volume 5, S. Kortz, N.L. Johnston and C.B. Read (Eds); Wiley, New York.

Hardwick, S. and Prestidge, R.A., 1994. Phenology of whitefringed weevil (Graphognathus leucoloma) in pasture in northern New Zealand. Proc. N.Z. Plant Prot. Conf. 47: 257-260.

Hartl, D.L., 1980. Principles of Population Genetics. Sinauer Associates, Inc., Sunderland, MA.

Hedrick, P., 1985. Genetics of Populations. Pp 72-73. Jones and Bartlett, Portoloa Valley, CA.

Hughes, R. N., 1989. Functional Biology of Clonal Animals. Chapman and Hall, London.

Kirby, L.T., 1990. DNA Fingerprinting: an Introduction. W.H. Freeman and Company, New York.

Lanteri, A.A. and Normark, B.B., 1995. Parthenogenesis in the tribe Naupactini (Coleoptera: Curculionidae). Ann. Ento. Soc. Am. 88: 722-731.

Lanteri, A.A. and Marvaldi, A.E., 1995.Graphognathus Buchanan, a new synonym of Naupactus Dejean, and the systematics of the N. leucolomaspecies group(Coleoptera: Curculionidae). Coleopt. Bull. 49: 206-228.

May, B.M.,1975. Whitefringed weevil Graphognathus leucoloma (Boheman), lifecycle. DSIR Information Series No. 105/12: 2pp.

Miller, S.A., Dykes, D.D. and Polesky, H.F., 1988. A simple salting out procedure for extracting DNA from human nucleated cells. Nucl. Acids Res. 16: 1215.

Nei, M. and Li, W.H., 1979. Mathematical model for studying genetic variation in terms of restriction endonucleases. Proc. Nat. Acad. Sci. U.S.A. 16: 5269-5273.

Nicol, D., Armstrong, K.F., Wratten, S.D., Cameron C.M., Frampton, C. and Fenton, B., 1997. Genetic variation in an introduced aphid pest (Metopolophium dirhodum) in New Zealand and relation to individuals from Europe. Mol. Ecol. 16: 225-265.

Sexton, S.B. and Williams, P., 1981. A natural occurrence of parasitism of Graphognathus leucoloma (Boheman) by the nematode Heterorhabditis sp. J. Aus. Ento. Soc. 20: 253-255.

Todd, D.H., 1968. Laboratory evaluation of insecticides against whitefringed weevil (Graphognathus leucoloma(Boheman) (Coleoptera: Curculionidae)).N.Z.J.Agri. Res. 163: 287-297.

Welsh, J.A and McClelland, M., 1990. Fingerprinting genomes using PCR with arbitrary primers. Nucl. Acids Res. 18: 7213-7218.

Williams, C.L., Goldson, S.L., Baird, D.B. and Bullock, D.W., 1994. Geographical origin of an introduced insect pest,Listronotus bonariensis (Kuschel), determined by RAPD analysis. Heredity 72: 412-419.

Williams, J.G.K., Kubelik, A.R., Livak, K.J., Rafalski, J.A. and Tingey, S.V., 1990. DNA polymorphisms amplified by arbitrary primers are useful as genetic markers. Nucl. Acids Res. 18: 6531-6535. 